\title{
De opmars van het uitleveringsrecht in de rechtspraak van het Hof van Justitie - het arrest Pisciotti nader beschouwd in het licht van eerdere Europese jurisprudentie en de Nederlandse uitleveringspraktijk
}

\author{
Mr. A.J. de Vries*
}

Recentelijk heeft het Hof van Justitie in de zaak Pisciotti opnieuw een oordeel gegeven over uitlevering van een EU-onderdaan naar een derde staat. ${ }^{1}$ Het arrest bouwt voort op eerdere revolutionaire rechtspraak en verduidelijkt de ingezette lijn van het Hof van Justitie. Om die reden is de uitspraak bijzonder interessant. In deze bijdrage bespreek ik het oordeel van het Hof van Justitie in Pisciotti. Vervolgens plaats ik het arrest in de context van eerdere Europese jurisprudentie over uitlevering. Ik bekijk ook welke implicaties de rechtspraak van het Hof van Justitie heeft voor de rechtspraktijk hier te lande.

Hvf (Grote Kamer) 10 april 2018, zaak C-191/16,

Romano Pisciotti/Bundesrepublik Deutschland, ECLI: EU:C:2018:222

\section{Inleiding}

Uitlevering is de oudste vorm van internationale samenwerking in de strafrechtelijke sferen. ${ }^{2}$ Binnen de EU is deze klassieke rechtsfiguur weliswaar vervangen door overlevering op grond van het Europees arrestatiebevel, maar in de betrekking met derde landen is uitlevering

Mr. A.J. (Aart) de Vries is promovendus aan de Universiteit Utrecht.

1. HvJ (Grote Kamer) 10 april 2018, zaak C-191/16, Romano Pisciotti/ Bundesrepublik Deutschland, ECLI:EU:C:2018:222.

2. P.D. Sutherland, 'The development of international law of extradition', Saint Louis University Law Journal 1984, nr. 1, p. 33-40; C.L. Blakesley, 'The Practice of Extradition from Antiquity to Modern France and the United States: A Brief History', Boston College International and Comparative Law Review 1981, nr. 1, p. 39-60. In de literatuur wordt gesteld dat de geschiedenis van het uitleveringsrecht is terug te voeren naar het Oude Egypte (1280 v. Chr.). nog steeds een belangrijk mechanisme. ${ }^{3}$ Uitlevering is geen automatisme; het betreft een procedure tussen soevereine staten waarin relatief veel ruimte bestaat om te weigeren een persoon over te dragen. Een belangrijk voorbeeld hiervan is dat veel staten hun eigen onderdanen niet uitleveren. Burgers kunnen zo binnen het territoir van het land van nationaliteit rekenen op bescherming tegen overbrenging naar een vreemde staat. Binnen de EU ligt de situatie gecompliceerder. Een van de pijlers van de Unie is het recht op vrij verkeer tussen de lidstaten. Bovendien zijn alle onderdanen van de lidstaten burgers van de EU en moeten zij in beginsel hetzelfde worden behandeld als de onderdanen van de lidstaat waar zij zich bevinden. Een EU-burger die

3. De termen uit- en overlevering hebben allebei betrekking op de situatie waarin een persoon van de ene naar de andere staat wordt overgebracht ten behoeve van strafvervolging of de tenuitvoerlegging van een opgelegde straf. Uit- en overlevering vertonen materieel dus veel gelijkenis en worden daarom weleens door elkaar gehaald in het normale taalgebruik. Toch is het belangrijk te differentiëren tussen de termen. Indien overbrenging geschiedt tussen lidstaten van de EU spreekt men sinds de invoering van Kaderbesluit 2002/584/JBZ van overlevering, terwijl de term uitlevering ziet op overbrenging vanuit een lidstaat van de EU naar een staat die geen deel uitmaakt van de Unie. Het verschil tussen de twee vormen van internationale samenwerking is niet louter semantisch. Uitlevering is bijvoorbeeld een procedure tussen soevereine staten, terwijl overlevering gekarakteriseerd wordt door direct contact tussen de bevoegde justitiële autoriteiten van de EU-lidstaten. Voorts zijn de weigeringsgronden in het overleveringsrecht sterk beperkt en is het overleveringssysteem gebaseerd op de Unierechtelijke figuren van wederzijds vertrouwen en wederzijdse erkenning. Zie voor een uitgebreid overzicht van en vergelijking tussen uit- en overlevering onder andere: H. Sanders, Handboek uitleverings- en overleveringsrecht, Deventer: Kluwer 2014; V.H. Glerum, De weigeringsgronden bij uitlevering en overlevering. Een vergelijking en kritische evaluatie in het licht van het beginsel van wederzijdse erkenning (diss. Amsterdam VU), Nijmegen: Wolf Legal Publishers 2013. Zie ook: Conclusie A-G RuizJarabo Colomer 12 december 2006, zaak C-303/05, Advocaten voor de Wereld, ECLI:EU:C:2006:552, punten 38-47. 
gebruikmaakt van zijn recht op vrij verkeer kan in een andere lidstaat dan die waarvan hij de nationaliteit bezit, geconfronteerd worden met een uitleveringsverzoek dat tegen hem is gericht. Omdat hij geen onderdaan is van de lidstaat waarin hij zich bevindt, geniet hij in zo een geval geen bescherming op grond van nationaliteit. Er is dan niet alleen sprake van ongelijke behandeling in vergelijking met de staatsburgers van deze lidstaat, maar ook van een beperking van het vrije verkeer. De waarde die in het uitleveringsrecht wordt toegekend aan nationaliteit staat zo op gespannen voet met deze Europeesrechtelijke noties. Recentelijk heeft het Hof van Justitie zich meermaals over deze materie uitgesproken. Het nieuwste arrest - Pisciotti - is gewezen in april 2018.

\section{Een trans-Atlantische saga - de zaak Pisciotti}

Waar gaat het om in het arrest? Pisciotti is een Italiaans staatsburger die tussen 1999 en 2006 mededingingsbeperkende afspraken heeft gemaakt in de VS. De Amerikaanse autoriteiten willen Pisciotti strafrechtelijk vervolgen en vaardigen een aanhoudingsbevel uit. In juni 2013 is de Italiaan op terugreis naar Italië als hij tijdens een tussenlanding in Frankfurt wordt aangehouden door de Duitse autoriteiten. De VS dient een officieel uitleveringsverzoek in. Duitsland wil Pisciotti uitleveren, maar hij vecht zijn overbrenging in rechte aan. De Italiaan wijst erop dat de Duitse grondwet niet toestaat dat Duitsers worden uitgeleverd en betoogt dat het toestaan van zijn uitlevering in strijd is met het Unierechtelijke discriminatieverbod. De Duitse rechter gaat daar niet in mee en de Italiaan wordt in 2014 overgebracht naar de VS. ${ }^{4}$ Op dezelfde dag dat zijn uitlevering wordt toegestaan, start Pisciotti een procedure tegen de Duitse staat. Tijdens de behandeling van de zaak wendt de Duitse rechter zich met enkele prejudiciële vragen tot het Hof van Justitie. Kort gezegd wil de rechter van het Hof van Justitie vernemen of de uitlevering van Pisciotti binnen de werkingssfeer van het Unierecht valt en, zo ja, of de Duitse grondwettelijke norm op grond waarvan in het uitleveringsrecht onderscheid wordt gemaakt tussen eigen onderdanen en onderdanen van andere lidstaten in strijd is met het Unierecht. ${ }^{5}$

Het Hof van Justitie bevestigt dat de zaak binnen de reikwijdte van het Unierecht valt, omdat de EU-VSovereenkomst inzake uitlevering van toepassing is. ${ }^{6}$ Het

4. T. Zimmermann, 'Der Fall "Pisciotti" vor dem EuGH. Oder: Vom Wert der Unionsbürgerschaft im Ausflieferungsrecht', Zeitschrift für Internationale Strafrechtsdogmatik 2017, nr. 4, p. 220-221.

5. Pisciotti, punt 30

6. Overeenkomst betreffende uitlevering tussen de Europese Unie en de Verenigde Staten van Amerika, PbEU 2003, L 181/27. Uitlevering zelf geschiedt op grond van de bilaterale verdragen tussen de VS en de individuele lidstaten van de EU, maar de EU-VS-overeenkomst zorgt voor uniformiteit in de toepassing van deze verschillende verdragen door de betreffende lidstaten. Zie in die context met name art. 3 van de uitleveringsovereenkomst.
Hof van Justitie brengt ook in herinnering dat het in eerdere rechtspraak al heeft overwogen dat situaties waarin een Unieburger gebruik heeft gemakt van zijn rechten op grond van het VWEU binnen de werkingssfeer van het Unierecht vallen, zelfs als er geen overeenkomst of verdrag bestaat tussen de EU en het verzoekende land. ${ }^{7}$ Vervolgens buigt het Hof van Justitie zich over de verenigbaarheid van het onderscheid dat op basis van de Duitse grondwet wordt gemaakt. De EU-VS-overeenkomst bepaalt in artikel 17 dat op grond van een bilateraal uitleveringsverdrag weigeringsgronden kunnen worden afgesproken in verband met een aangelegenheid die niet wordt geregeld door de overeenkomst. Het uitleveringsverdrag tussen de VS en Duitsland biedt de mogelijkheid om eigen onderdanen niet uit te leveren. Zodoende staat de EU-VS-overeenkomst lidstaten toe een bijzondere behandeling te bieden aan hun onderdanen, maar dit moet wel in lijn zijn met het primaire Unierecht. Daarbij wijst het Hof van Justitie in het bijzonder op de regels inzake gelijke behandeling en vrij verkeer. Het Hof van Justitie overweegt dat het onderscheid tussen staatsburgers en onderdanen van andere lidstaten de vrijheid van verkeer van laatstgenoemden nadelig kan beinvloeden; zij genieten immers minder bescherming tegen uitlevering dan staatsburgers. ${ }^{8}$ Een beperking moet gebaseerd zijn op objectieve overwegingen en evenredig zijn aan het rechtmatig nagestreefde doel. ${ }^{9}$ Het voorkomen van straffeloosheid vormt binnen de ruimte van vrijheid, veiligheid en recht een legitiem doel, maar het Hof van Justitie benadrukt dat maatregelen die een fundamentele vrijheid beperken alleen kunnen worden gerechtvaardigd, indien zij noodzakelijk zijn ter bescherming van de belangen die zij beogen te waarborgen en die doelstelling niet met minder beperkende maatregelen bereikt kan worden. ${ }^{10} \mathrm{Om}$ die reden stelt het Hof van Justitie dat de aangezochte staat eerst contact moet leggen met en informatie moet verstrekken aan de lidstaat waarvan de betrokkene de nationaliteit bezit, wanneer een derde staat om uitlevering verzoekt. In zo een geval kan de thuisstaat van de betrokkene besluiten een Europees aanhoudingsbevel (EAB) uit te vaardigen. Het EAB moet minstens op dezelfde feiten betrekking hebben en de thuisstaat moet ook werkelijk in staat zijn de betrokkene te vervolgen, ook als de feiten buiten zijn territoir zijn begaan. ${ }^{11}$ Bovendien betreft het uitvaardigen van

7. Pisciotti, punten 32-33.

8. Het gaat er hier dus niet om of de opgeëiste persoon minder bescherming krijgt in vergelijking met zijn thuisstaat, maar of hij in vergelijking met de staatsburgers van de lidstaat waar hij zich bevindt ongelijk wordt behandeld en daardoor minder bescherming krijgt. De situatie in de thuisstaat kan wel van belang zijn voor (het bestaan van een plicht tot) het uitvaardigen van een EAB, zie: $M$. João Costa, 'The emergence of EU extradition law. Petruhhin and beyond', New Journal of European Criminal Law 2017, nr. 2, p. 192-215, op p. 204-205.

9. Pisciotti, punt 47

10. Pisciotti, punt 47. Zie ook: HvJ (Grote Kamer) 27 mei 2014, zaak C-129/14 PPU, Zoran Spasic, ECLI:EU:C:2014:586, punten 63-65.

11. Pisciotti, punt 54. Dit vergt dus dat de lidstaat van herkomst rechtsmacht heeft - bijvoorbeeld op grond van het actieve nationaliteitsbeginsel - en dat de gepleegde misdrijven ook daar te lande strafbaar zijn. Het feit dat de Italiaanse autoriteiten geen EAB hebben uitgevaardigd, 
een EAB geen automatisme, aldus het Hof van Justitie. In de zaak van Pisciotti zijn de Italiaanse autoriteiten voorafgaand aan de uitlevering voortdurend op de hoogte gehouden van zijn situatie, maar zij hebben geen Europees aanhoudingsbevel uitgevaardigd. Op grond daarvan stelt het Hof van Justitie vast dat de uitlevering van de Italiaan noodzakelijk was en geen minder beperkende maatregel voorhanden was. Het Unierecht verzet zich in dat geval niet tegen het feit dat de aangezochte staat op basis van een grondwettelijke norm onderscheid maakt tussen zijn staatsburgers en onderdanen van andere lidstaten wat betreft de (on)toelaatbaarheid van uitlevering. ${ }^{12}$ De beperking van het vrije verkeer is gerechtvaardigd.

\section{De opkomst van Europees uitleveringsrecht}

In 2016 heeft het Hof van Justitie in het arrest Petruhhin geoordeeld dat uitlevering binnen de werkingssfeer van het Unierecht kan komen en dat onderscheid tussen EU-burgers van andere lidstaten en eigen onderdanen ook in die context gerechtvaardigd moet worden. ${ }^{13}$ De zaak had betrekking op een Russisch uitleveringsverzoek voor de vervolging van de Est Aleksei Petruhhin dat in Letland werd behandeld. Het Letse nationale recht en het uitleveringsverdrag dat het land had gesloten met Rusland bepaalden dat uitlevering van Letse staatsburgers niet werd toegestaan, maar dat vormde geen obstakel voor de overbrenging van Petruhhin. De hoogste Letse rechter meende dat het gemaakte onderscheid in strijd was met de kern van het Unieburgerschap - het recht op gelijke behandeling en gelijke bescherming in vergelijking met staatsburgers - en legde de zaak voor aan het Hof van Justitie. ${ }^{14}$ Advocaat-generaal Bot stelde in zijn conclusie dat de zaak van Petruhhin binnen de reikwijdte van het Unierecht viel, omdat de Est gebruik had gemaakt van zijn recht op vrij verkeer. Het onderscheid op grond van nationaliteit in het Letse uitleveringsrecht vormde een belemmering voor het vrije verkeer, maar het voorkomen van straffeloosheid bood voldoende rechtvaardiging. Een minder ingrijpend alternatief was niet voorhanden, omdat Letland Petruhhin niet kon vervolgen. ${ }^{15}$ Het Hof van Justitie volgde de advo-

hangt volgens A-G Bot samen met de omstandigheid dat de gedragingen van Pisciotti geen strafbare feiten vormden naar Italiaans recht. Zie: Conclusie A-G Bot 21 november 2017, zaak C-191/16, Romano Pisciotti/Bundesrepublik Deutschland, ECLI:EU:C:2017, punt 35.

12. Pisciotti, punt 56

13. HvJ (Grote Kamer) 6 september 2016, zaak C-182/15, Aleksei Petruhhin, ECLI:EU:C:2016:630.

14. Petruhhin, punten 10-17.

15. Conclusie A-G Bot 10 mei 2016, zaak C-182/15, Aleksei Petruhhin, ECLI:EU:C:2016:330. De A-G wijst hierbij op het bekende adagium 'aut dedere, aut judicare' dat voorschrijft dat gevolg moet worden gegeven aan het uitleveringsverzoek of - als dat niet kan of mag - door de aangezochte staat zelf vervolging ingesteld moet worden. Zo wordt voorkomen dat een persoon die niet kan worden uitgeleverd straffeloos blijft. caat-generaal wat betreft de argumentatie dat de zaak van Petruhhin binnen de reikwijdte van het Unierecht viel, maar koos voor een andere benadering ten aanzien van de rechtvaardiging van de beperking. De aangezochte lidstaat moet informatie uitwisselen met de thuisstaat van de opgeëiste Unieburger teneinde die lidstaat in staat te stellen een EAB uit te vaardigen. Door zo samen te werken en door aan een EAB voorrang te geven boven het uitleveringsverzoek wordt een beter evenwicht gevonden tussen vrij verkeer en het tegengaan van straffeloosheid. ${ }^{16}$

Het belang van Petruhhin is niet zozeer gelegen in het oordeel dat de beperking van het vrije verkeer ook in het uitleveringsrecht moet worden gerechtvaardigd, maar in de erkenning dat deze klassieke rechtsfiguur binnen de werkingssfeer van het Unierecht valt. ${ }^{17}$ Het feit dat alle lidstaten behalve het Verenigd Koninkrijk tijdens de procedure voor het Hof van Justitie hebben bepleit dat uitlevering niet binnen de eerdergenoemde reikwijdte kan komen bij gebrek aan een Unierechtelijke overeenkomst, spreekt boekdelen. ${ }^{18}$ Daarnaast is de procedure die het Hof van Justitie voorschrijft vernieuwend. In de literatuur wordt daarom gesteld dat sprake is van een 'emerging EU extradition law' en dat zich een 'unexpected revolution in extradition law' heeft voorgedaan. ${ }^{19}$ Deze revolutie wordt door het Hof van Justitie voortgezet in Pisciotti. De zaak is - net als Petruhhin door de Grote Kamer behandeld. Dit geeft aan dat uitlevering van EU-onderdanen naar derde staten een 'uitzonderlijk belang' heeft in de ogen van het Hof van Justitie. Het feit dat het in Pisciotti draait om uitlevering aan de VS makt het oordeel van het Hof van Justitie nog specialer: de EU heeft momenteel alleen met dat land een uitleveringsovereenkomst gesloten. ${ }^{20}$ In Petruhhin is het belangrijkste twistpunt nog of het uitleveringsrecht binnen de reikwijdte van het Unierecht

16. Petruhhin, punten 48-49. In deze bijdrage laat ik de beoordeling van het Hof van Justitie over art. 19 Handvest buiten beschouwing, omdat dit gedeelte van het arrest in relatie tot Pisciotti niet relevant is. Het oordeel is mijns inziens in lijn met eerdere rechtspraak die behelst dat het Unierecht in lijn moet zijn met het Handvest, bijvoorbeeld: HvJ (Grote Kamer) 5 april 2016, gevoegde zaken C-404/15 en C-659/15 PPU, Aranyosi en Căldăraru, ECLI:EU:C:2016:198; HvJ 6 september 2017, zaak C-473, Peter Schotthöfer \& Florian Steiner GbR, ECLI:EU:C: 2017:633. Zie hierover uitgebreid: E. Filius, 'De zoektocht naar de balans tussen de Unierechtelijke verplichtingen en de naleving van internationale overeenkomsten net derde landen', DD 2018/57, par. 2.1 en 2.3 .

17. V. Glerum, 'Bescherming van een onderdaan van een andere lidstaat tegen uitlevering aan een derde land', SEW 2017, nr. 4, p. 172. Zie ook: HvJ 6 september 2017, zaak C-473, Peter Schotthöfer \& Florian Steiner GbR, ECLI:EU:C:2017:633. Uit dit arrest kan worden afgeleid dat ook zaken waarin nog geen gebruik is gemaakt van het recht op vrij verkeer onder de reikwijdte van het Unierecht kunnen vallen.

18. Conclusie A-G Bot 10 mei 2016, zaak C-182/15, Aleksei Petruhhin, ECLI:EU:C:2016:330, punt 33.

19. João Costa 2017; A.H. Klip, 'Europeans First!: Petruhhin, an Unexpected Revolution in Extradition Law', European Journal of Crime, Criminal Law and Criminal Justice 2017, nr. 3, p. 195-204.

20. Overeenkomst betreffende uitlevering tussen de Europese Unie en de Verenigde Staten van Amerika, Trb. 2004, 297. Het bestaan van de overeenkomst maakt het oordeel van het Hof van Justitie dat de zaak Pisciotti binnen de werkingssfeer van het Unierecht komt weinig verrassend. 
komt bij het ontbreken van een uitleveringsovereenkomst, maar in Pisciotti speelt die vraag geen rol meer. De centrale rol die de beperking van het vrije verkeer tussen de lidstaten inneemt in Petruhhin had zodoende naar de achtergrond kunnen verdwijnen, maar dat is niet het geval. De Grote Kamer herhaalt de relevante overwegingen uit de eerdere rechtspraak expliciet. Dit obiter dictum onderstreept dat het vrije verkeer een fundamentele, zelfstandige grond vormt om uitlevering onder het Unierecht te scharen, zelfs als er een overeenkomst met een derde land bestaat.

\section{Losse eindjes in de Europese rechtspraak}

Het Hof van Justitie bouwt in Pisciotti voort op eerdere jurisprudentie, maar dat betekent niet dat alle implicaties van de rechtspraak nu duidelijk zijn. Een interessant punt betreft de voorrangsregels tussen uitleveringsverzoeken en EAB's. Verschillende lidstaten betogen dat het mechanisme dat door het Hof van Justitie is geintroduceerd in Petruhhin zorgt voor automatische voorrang van een $\mathrm{EAB}$ op een uitleveringsverzoek. Het Hof van Justitie verwerpt die stelling en verduidelijkt dat het slechts gaat om een mogelijkheid. Een EAB moet alleen voorrang krijgen, indien het om dezelfde feiten gaat en de thuisstaat bevoegd is de opgeëiste persoon daar te lande te vervolgen, zelfs als de feiten buiten diens territoir zijn gepleegd. De samenloopregels uit de EU-VSovereenkomst zijn in alle andere gevallen nog steeds relevant en bruikbaar. Het Hof van Justitie verduidelijkt dus dat overlevering niet per definitie voorrang heeft op uitlevering. Ik vraag me af of het Hof van Justitie met deze overweging werkelijk antwoord geeft op de vraag die door de lidstaten naar voren is gebracht. Ik vermoed dat zij de automatische voorrang van een EAB dat is uitgevaardigd voor dezelfde feiten en die door de thuisstaat kunnen worden vervolgd aan de kaak wilden stellen. Uit Petruhhin en Pisciotti valt namelijk nog steeds af te leiden dat het Unierecht in een dergelijk geval eist dat de opgeëiste persoon wordt overgeleverd naar de lidstaat van nationaliteit en dat dus voorrang wordt gegeven aan het EAB. Dit betekent niet alleen dat de jurisprudentie van het Hof van Justitie een impliciete rechtsmachtstoedeling bevat, maar ook dat de aangezochte lidstaat zijn - vaak oudere - verdragsverplichting jegens de derde staat niet kan nakomen. ${ }^{21}$

Een aspect dat door het Hof van Justitie in zowel Petruhhin als Pisciotti buiten beschouwing wordt gelaten, betreft het effect van de rechtspraak voor de inter-

21. HvJ (Grote Kamer) 6 september 2016, zaak C-182/15, Aleksei Petruhhin, ECLI:EU:C:2016:630, NJ 2017, 391 m.nt. A.H. Klip. Zie ook Glerum 2017, p. 174. Glerum onderscheidt (in de context van Petruhhin) eveneens een botsing van verplichtingen en oppert dat het Hof van Justitie zijn oordeel gebaseerd heeft op art. $351 \mathrm{VWEU}$. Dat is inderdaad mogelijk, maar het was de inzichtelijkheid ten goede gekomen als het Hof van Justitie dat benoemd had in de uitspraak. nationale rechtshulp in strafzaken in het algemeen. ${ }^{22} \mathrm{De}$ procedure die het Hof van Justitie heeft geintroduceerd - het uitvaardigen van een EAB - is vanuit een 'eurocentrisch' perspectief creatief en toe te juichen, maar het Hof van Justitie lijkt vergeten te zijn dat een derde staat nog steeds een belangrijke - zo niet doorslaggevende rol kan spelen als er geen uitlevering plaatsvindt. ${ }^{23}$ Indien een derde staat een uitleveringsverzoek indient, is de kans groot dat het bewijs van gepleegde misdrijven zich daar te lande bevindt; anders zou het derde land in de regel niet om uitlevering verzoeken. Het feit dat een persoon niet wordt uitgeleverd aan dat derde land, maar in plaats daarvan wordt overgeleverd naar de lidstaat van de EU waarvan hij de nationaliteit bezit, betekent niet dat hij in zijn thuisstaat zonder meer (met succes) vervolgd kan worden. Daarvoor is dikwijls nodig dat de thuisstaat via instrumenten van internationale rechtshulp beschikking krijgt over de bewijsmiddelen die zich bevinden in de derde staat. Het is mogelijk dat de derde staat voor het hoofd gestoten is als de voorkeur wordt gegeven aan een $\mathrm{EAB}$ en daardoor minder vlug geneigd is mee te werken. Het valt niet uit te sluiten dat zich in een specifieke zaak spanningen voordoen die de rechtshulp bemoeilijken. Dat is onwenselijk, omdat het kan leiden tot straffeloosheid in een bepaalde zaak als noodzakelijk bewijs uit een derde land niet wordt overdragen naar een EU-lidstaat. ${ }^{24}$ Aan het voorkomen van straffeloosheid binnen de EU wordt in Petruhhin en Pisciotti juist veel waarde toegekend, maar dat vertaalt zich opvallend genoeg niet in een overweging van het Hof van Justitie over de gevolgen voor de betrekking met derde staten.

Een derde vraag die in de literatuur over Petruhhin naar voren is gebracht en die ook in Pisciotti onbeantwoord blijft, is of de door het Hof van Justitie voorgeschreven procedure geldt voor zowel vervolgings- als executieuitlevering. Hoewel het in beide gevallen gaat om uitlevering, verschillen de vormen van elkaar wat betreft de praktische implicaties van de Europese rechtspraak. Bij vervolgingsuitlevering moet de thuisstaat immers een EAB uitvaardigen en de opgeëiste persoon zelf vervolgen, maar bij executie-uitlevering moet de tenuitvoerlegging van de derde staat worden overgenomen. ${ }^{25}$ Daarnaast lopen de belangen die gediend worden door

22. De overweging van het Hof van Justitie dat het uitvaardigen van een $E A B$ geen automatisme is, kan mijns inziens niet worden gezien als een handreiking naar derde staten. Zoals gezegd hangt het feit dat geen sprake is van een automatisch EAB blijkens de bewoordingen van het Hof van Justitie samen met de eis dat de thuisstaat rechtsmacht heeft en dat het feit daar te lande strafbaar is. Het belang van goede rechtsbetrekkingen met derde landen wordt in het geheel niet genoemd. In deze context wijs ik op de rechtspraak van het EHRM waar wel een duidelijke plek wordt toegekend aan de internationale rechtsbetrekkingen. Zie: EHRM 26 juni 1992, nr. 12747/87, Drozd en Janousek t. Frankrijk en Spanje.

23. Zie: Glerum 2017, p. 173.

24. Glerum 2017, p. 173. Glerum wijst erop dat het risico bestaat dat de vervolging moet worden gestaakt. Dat leidt tot straffeloosheid.

25. Het uitvaardigen van een $E A B$ is in dat soort gevallen ook geen passende oplossing, omdat er geen onherroepelijk vonnis is van een Uniestrafrechter. Zie: Conclusie A-G Bot 25 juli 2018, zaak C-247/17, Denis Raugevicius, ECLI:EU:C:2018:616, punten 55 en 56. 
de twee uitleveringsvormen uiteen. Bij vervolgingsuitlevering wordt recht gedaan aan het belang van de verzoekende staat om een gepleegd misdrijf te adresseren en straffeloosheid te voorkomen. Bij executie-uitlevering ligt de zaak anders; het tegengaan van straffeloosheid en vergelding blijven van belang, maar ook de resocialisatie van de veroordeelde speelt een rol. In zowel Petruhhin als Pisciotti ging het om uitlevering ten behoeve van vervolging, maar de bewoordingen van de arresten kunnen - ondanks de voornoemde verschillen - naar de letter ook toepasbaar zijn op executie-uitlevering. Over deze vraag wordt een procedure gevoerd voor het Hof van Justitie in de zaak Raugevicius. ${ }^{26}$ Het oordeel van het Hof van Justitie is nog niet bekend, maar advocaat-generaal Bot heeft al wel geconcludeerd in de zaak. Kort gezegd onderkent de advocaat-generaal het verschil tussen vervolgings- en executie-uitlevering en geeft hij het Hof van Justitie in overweging dat het mechanisme uit Petruhhin niet onverkort kan gelden in geval van executie-uitlevering. In plaats daarvan moet de aangezochte lidstaat bekijken of de opgelegde straf op zijn grondgebied tenuitvoergelegd kan worden. ${ }^{27}$

\section{Het Nederlandse uitleveringsrecht en Pisciotti}

In tegenstelling tot veel andere staten bestaat in Neder-

land geen constitutionele bepaling die de uitlevering van staatsburgers verbiedt. ${ }^{28}$ Artikel 2 lid 3 van de Grondwet bepaalt wel dat uitlevering alleen kan geschieden krachtens een verdrag en dat verdere voorschriften bij de wet worden gegeven. ${ }^{29}$ De aanvullende regels zijn te

26. Verzoek om een prejudiciële beslissing ingediend door de Korkein oikeus (Finland) op 16 mei 2017 - Oikeusministeriö/Denis Raugevicius (zaak C-247/17), PbEU 2017, C 239/30. De feiten van het arrest zijn als volgt. Raugevicius heeft zowel de Litouwse als de Russische nationaliteit, maar woont al jaren in Finland. Hij is getrouwd en heeft twee kinderen die Fins staatsburger zijn. Rusland heeft Finland verzocht Raugevicius uit te leveren voor de tenuitvoerlegging van een vrijheidsstraf. Naar Fins recht kunnen alleen onderdanen niet worden uitgeleverd. De hoogste Finse rechter vraagt zich af of de procedure uit Petruhhin moet worden gevolgd en legt deze vraag voor aan het Hof van Justitie.

27. Conclusie A-G Bot 25 juli 2018, zaak C-247/17, Denis Raugevicius, ECLI:EU:C:2018:616, punten 81-83. Dit oordeel hangt nauw samen met het feit dat Raugevicius al jaren in Finland woont met zijn vrouw en Finse kinderen. Het belang van resocialisatie maakt in zo een situatie dat tenuitvoerlegging in Finland passend is. De vraag rijst of het mechanisme dat A-G Bot voorstelt ook geldt, indien een duidelijke band met de aangezochte lidstaat niet bestaat.

28. Tot 1983 bepaalde de Grondwet dat Nederlanders niet uitgeleverd konden worden. Voor de redenen voor de koersverandering zie: Glerum 2013, p. 381. Zie eveneens: Z. Deen-Racsmány, Active Personality and Non-extradition of Nationals in International Criminal Law at the Dawn of the Twenty-first Century (diss. Leiden), Leiden: Leiden University Press 2007

29. Het kan hier gaan om een bilateraal (bijvoorbeeld het uitleveringsverdrag tussen de VS en Nederland, Trb. 2010, 5) of multilateraal uitleveringsverdrag (bijvoorbeeld het Europees verdrag betreffende uitlevering, Trb. 1965, 9). Het is ook mogelijk dat uitlevering plaatsvindt op grond van een mondiaal verdrag dat niet specifiek betrekking heeft op uitlevering, maar daar wel bepalingen over bevat (bijvoorbeeld het Internationaal Verdrag ter bestrijding van de financiering van terrorisme van vinden in de Uitleveringswet. In het licht van Petruhhin en Pisciotti is artikel 4 van de Uitleveringswet van bijzonder belang. Het eerste lid van die bepaling stelt weliswaar dat Nederlanders niet worden uitgeleverd, maar artikel 4 lid 2 bepaalt dat het eerste lid niet van toepassing is als de uitlevering van een Nederlander is gevraagd ten behoeve van vervolging en naar het oordeel van de minister is gewaarborgd dat hij de straf die mogelijk wordt opgelegd in ons land mag ondergaan. Uit artikel 4 Uitleveringswet blijkt allereerst dat Nederland zijn onderdanen niet uitlevert ten behoeve van vervolging, behalve als er een terugkeergarantie wordt gegeven door de verzoekende staat. In zo een geval wordt de opgeëiste persoon uitgeleverd, maar heeft hij het recht om na een eventuele veroordeling te vragen om terugkeer naar Nederland. Voor de overdracht van de tenuitvoerlegging is toestemming nodig van beide betrokken staten, maar de garantie die de verzoekende staat in de uitleveringsprocedure heeft verstrekt, neemt de mogelijkheid weg om terugkeer te weigeren. ${ }^{30}$ Voorts kan uit artikel 4 a contrario worden afgeleid dat Nederland nooit onderdanen uitlevert voor de executie van een straf. In zulke gevallen kan de tenuitvoerlegging wel worden overgenomen. Als laatste kan worden geconcludeerd dat de Uitleveringswet niet in de weg staat aan de overdracht aan een derde staat van personen die de Nederlandse nationaliteit niet bezitten. Dat geldt zowel voor vervolgings- als executie-uitlevering; de eis van een garantie respectievelijk het algehele verbod op uitlevering voor tenuitvoerlegging werken dan niet.

\section{Unieburgers uit andere lidstaten in Nederland - uitleveren of overleveren?}

Wat betekenen de uitspraken van het Hof van Justitie voor het uitleveringsrecht hier te lande? Ook in het Nederlandse uitleveringsrecht wordt onderscheid gemaakt op grond van nationaliteit. Dat moet worden gerechtvaardigd. In deze context is relevant dat de Hoge Raad zich in 2008 al eens heeft uitgesproken over de (executie-)uitlevering van een Unieburger aan Kroatië. ${ }^{31}$ De Hoge Raad liet toen in het midden of het uitleveringsrecht binnen de reikwijdte van het Unierecht viel, maar oordeelde dat er in elk geval een redelijke en objectieve rechtvaardiging bestond voor het gemaakte onderscheid. ${ }^{32}$ De Hoge Raad koos in het arrest dus voor een vergelijkbare benadering als advocaat-generaal

9 december 1991, Trb. 2000, 12). In de laatste twee gevallen is het vanzelfsprekend wel vereist dat beide staten partij zijn bij dat verdrag.

30. Glerum 2013, p. 385.

31. HR 11 november 2008, ECLI:NL:HR:2008:BC9546. In 2008 was Kroatië (nog) geen lidstaat van de EU.

32. HR 11 november 2008, ECLI:NL:HR:2008:BC9546, punt 3.7.2. Nederland kon de opgeëiste persoon niet alsnog vervolgen of hem zijn straf laten ondergaan. 
Bot in de conclusie bij Petruhhin. ${ }^{33}$ Naar huidig recht moet Nederland, wanneer het een uitleveringsverzoek krijgt uit een derde staat voor een burger uit een andere lidstaat van de EU, contact opnemen met de autoriteiten daar te lande en informatie uitwisselen. Vervolgens bestaat de mogelijkheid voor de bevoegde autoriteiten in de andere lidstaat om een EAB uit te vaardigen. ${ }^{34}$ Dit EAB moet betrekking hebben op dezelfde feiten en de thuisstaat moet bevoegd zijn de opgeëiste persoon te vervolgen, zelfs als de feiten buiten het territoir zijn gepleegd. In zo een geval is er een alternatief voorhanden dat het vrije verkeer en het risico op straffeloosheid minder beperkt dan uitlevering. Nederland moet voorrang geven aan het $\mathrm{EAB}$ boven het uitleveringsverzoek. Of deze procedure ook gevolgd moet worden in gevallen van executie-uitlevering is nog onduidelijk.

In de Nederlandse rechtspraktijk speelt Pisciotti nog geen grote rol; ik heb één voorbeeld gevonden van een beroep op het arrest in het uitleveringsrecht. ${ }^{35}$ Hieruit mag mijns inziens niet worden geconcludeerd dat de relevantie van het arrest te verwaarlozen is. Het betreft een recent oordeel. In de krappe twee jaar na het oordeel in Petruhhin is wel meermaals een beroep op dat arrest gedaan in Nederlandse uitleveringszaken. ${ }^{36}$ De eerste zaak heeft betrekking op vervolgingsuitlevering van een Pools staatsburger naar Oekraine. ${ }^{37}$ Voor de Rechtbank Den Haag beargumenteert de verdediging dat de behandeling van het uitleveringsverzoek moet worden aangehouden, zodat de Poolse autoriteiten de mogelijkheid hebben om een EAB uit te vaardigen en de strafvervolging over te nemen van Oekraine. De rechtbank gaat daar niet in mee en oordeelt dat het naar Nederlands recht niet aan de uitleveringsrechter is om contact te leggen met Polen. Die taak rust bij de minister en dient te lopen via de diplomatieke kanalen. In cassatie houdt dit oordeel stand. ${ }^{38}$ De overige zaken die ik heb ange-

33. Conclusie A-G Bot 10 mei 2016, zaak C-182/15, Aleksei Petruhhin, ECLI:EU:C:2016:330.

34. João Costa 2017, p. 204. Hoewel de rechtspraak van het Hof van Justitie geen dwingende bewoordingen bevat, meent João Costa dat er in het licht van de ratio achter het oordeel in Petruhhin een plicht aangenomen moet worden tot het uitvaardigen van een $E A B$ als dat mogelijk is.

35. Hof Den Haag 26 juni 2018, ECLI:NL:GHDHA:2018:1767. Het betreft hier een verwijzing naar Petruhhin en Pisciotti. Het gaat in de zaak om een Turks uitleveringsverzoek jegens een Bulgaar ten behoeve van tenuitvoerlegging. In een recente uitspraak van de Rechtbank Amsterdam in een overleveringszaak worden Petruhhin en Pisciotti eveneens genoemd. De verdediging wilde dat prejudiciële vragen werden gesteld aan het Hof van Justitie over de implicaties van beide uitspraken voor het overleveringsrecht. De rechter ging daar niet in mee, omdat overen uitlevering fundamenteel verschillen; bij overlevering blijft een opgeeiste persoon immers binnen de EU. Zie: Rb. Amsterdam 12 juni 2018, ECLI:NL:RBAMS:2018:5111. Zie ook: Rb. Amsterdam 13 december 2016, ECLI:NL:RBAMS:2016:8435. In deze overleveringszaak werd een (onsuccesvol) beroep gedaan op Petruhhin

36. In zijn noot bij het arrest Petruhhin geeft Klip aan dat er op het moment van schrijven van die bijdrage geen jurisprudentie te vinden was waarin de uitspraak een rol speelde. Een jaar later is dat anders, zoals blijkt uit de hoofdtekst. Om die reden denk ik dat de zaak Pisciotti - vermoedelijk dikwijls in combinatie met de zaak Petruhhin - ook zichtbaarder zal worden in de nationale uitleveringsrechtspraak.

37. Rb. Den Haag 31 augustus 2017, ECLI:N:RBDHA:2017:9893.

38. HR 23 februari 2018, ECLI:NL:HR:2018:289, punt 4.3. troffen hebben betrekking op executie-uitlevering. Eén zaak betreft de uitlevering van een Griekse onderdaan naar Rusland. De verdediging betoogt onder andere dat de Nederlandse autoriteiten de verplichtingen op grond van Petruhhin niet hebben nageleefd. Zij hadden Griekenland geinformeerd over het uitleveringsverzoek en gevraagd of de bevoegde autoriteiten een EAB wilden uitvaardigen. Volgens de verdediging kon hierop alleen ontkennend worden geantwoord en had de vraag voorts moeten zijn of Griekenland de tenuitvoerlegging wilde overnemen van Rusland. De Rechtbank Den Haag volgt het verweer niet en overweegt dat uit Petruhhin alleen valt af te leiden dat er een verplichting bestaat tot het uitwisselen van informatie. Die verplichting is nagekomen. De Grieken hadden alle relevante informatie, ook dat het in de zaak ging om executie-uitlevering. Het is vervolgens aan de autoriteiten daar te lande om te bepalen welk instrument aangewend moet worden. ${ }^{39}$ In een andere zaak staat de reikwijdte van de informatieverplichting van de Nederlandse autoriteiten eveneens centraal. ${ }^{40}$ Uit het oordeel van het Hof Den Haag kan worden afgeleid dat de reikwijdte afhangt van de omstandigheden van het geval. In de desbetreffende zaak kon niet worden volstaan met een standaardbrief over het ontvangen uitleveringsverzoek en een algemeen geformuleerde vraag of de buitenlandse autoriteiten een EAB wilden uitvaardigen, omdat een gemotiveerd beroep werd gedaan op een dreigende schending van de artikelen 8 EVRM en 7 Handvest. Er had specifieke informatie moeten worden verstrekt door de minister, bijvoorbeeld over de gezinssituatie van de opgeëiste persoon. ${ }^{41}$

\section{Nederlanders in andere lidstaten}

\section{- terug naar huis?}

De bovenstaande rechtspraak heeft steeds betrekking op buitenlandse Unieburgers voor wie een uitleveringsverzoek aan Nederland wordt gedaan. Stel dat een Nederlander zich in een andere lidstaat bevindt en daar geconfronteerd wordt met een uitleveringsverzoek uit een derde staat. Moet Nederland in zo een geval een EAB uitvaardigen om de persoon naar huis te halen? Voor vervolgingsuitlevering is op basis van de Europese rechtspraak allereerst van belang of Nederland bevoegd is om de gepleegde strafbare feiten hier te vervolgen. ${ }^{42}$ Ook als dat het geval is, vraag ik me af of een EAB uitgevaardigd moet worden. ${ }^{43}$ Nederlanders kunnen naar

39. Rb. Den Haag 2 november 2017, ECLI:NL:RBDHA:2017:12708, punten 4.12.-4.15.

40. Hof Den Haag 26 juni 2018, ECLI:NL:GHDHA:2018:1767.

41. Hof Den Haag 26 juni 2018, ECLI:NL:GHDHA:2018:1767, punt 12.

42. Zie in deze context Eerste Boek, Titel I Wetboek van Strafrecht.

43. João Costa 2017, p. 205. João Costa meent dat 'the Petruhhin principle does not seem to apply if the Member State of which the person is a national would itself extradite him/her, since in that event one element is missing which is indispensable to elicit the EU citizenship exception: an impairment of free movement'. João Costa heeft mijns inziens gelijk, indien hij doelt op landen die hun burgers ongeclausuleerd en onvoorwaardelijk uitleveren. Zoals gezien, vraagt Nederland om een garantie 
nationaal recht worden uitgeleverd ten behoeve van vervolging, mits er een terugkeergarantie bestaat. Als Nederland in het geval van een uitleveringsverzoek ten behoeve van vervolging een EAB uitvaardigt, bestaat er formeel geen beletsel de opgeëiste persoon alsnog vanuit Nederland uit te leveren met een terugkeergarantie als het verzoek herhaald wordt jegens de Nederlandse autoriteiten. ${ }^{44}$ Als men kiest voor deze optie wordt een flinke omweg genomen die leidt tot (onnodige) vertraging. Ik vraag me af of het niet effectiever is als Nederland via diplomatieke kanalen betracht een terugkeergarantie te verkrijgen van de derde staat waarna de EU-lidstaat waar de Nederlander zich bevindt, uitlevert. Mijns inziens is deze handelswijze mogelijk, omdat de Nederlandse autoriteiten door de aangezochte lidstaat geïnformeerd zullen worden over een uitleveringsverzoek en zij daarop kunnen acteren. Dit leidt tot een identieke situatie in vergelijking met vervolgingsuitlevering door Nederland zelf; de opgeëiste persoon kan na berechting terugkeren. Dit vergt wel dat Nederland 'inbreekt' in de uitleveringsprocedure tussen twee soevereine staten en dat verhoudt zich moeizaam met de fundamentele beginselen van het uitleveringsrecht. De situatie is bij uitleveringsexecutie nog gecompliceerder. Nederland levert in zulke gevallen per definitie geen onderdanen uit. Het zou dus passend zijn om een EAB uit te vaardigen, maar die optie bestaat alleen als er een rechterlijke uitspraak van een Unierechter aan dat EAB ten grondslag ligt. De enige mogelijkheid die ik zie, is dat Nederland, nadat de autoriteiten geïnformeerd zijn over het uitleveringsverzoek in een andere lidstaat, contact legt met de derde staat en tracht de tenuitvoerlegging over te nemen. In dat geval zorgt de exequaturprocedure uit de Wet overdracht tenuitvoerlegging strafvonnissen ervoor dat het buitenlandse vonnis wordt omgezet naar een Nederlandse beslissing. ${ }^{45}$ Deze beslissing kan dan de basis vormen voor het uitvaardigen van een EAB. Ook hier zitten haken en ogen aan, bijvoorbeeld dat de derde staat partij moet zijn bij een verdrag op basis waarvan overdracht van de tenuitvoerlegging kan geschieden en voorts ook akkoord gaat met de overdracht van de executie aan Nederland. ${ }^{46}$

\section{Conclusie}

Pisciotti is een interessante uitspraak en een belangrijke nieuwe stap na het revolutionaire arrest Petruhhin. Het feit dat de Grote Kamer zich in Pisciotti opnieuw over een uitleveringszaak heeft gebogen, spreekt boekdelen: de bescherming van Unieburgers in de context van uitlevering naar derde staten staat hoog op de agenda. Het Hof van Justitie heeft meer duidelijkheid gebracht, bijvoorbeeld wat betreft de voorrangsregels tussen uitleveringsverzoeken en uitgevaardigde EAB's. Desalniettemin blijven belangrijke vragen bestaan. Het ligt in de lijn der verwachting dat het Hof van Justitie zich in de toekomst vaker gaat (moeten) buigen over het uitleveringsrecht. De directe invloed van Pisciotti op de Nederlandse rechtspraktijk is nog beperkt, maar het toegenomen aantal verwijzingen naar het oordeel in Petruhhin doet vermoeden dat dit in de nabije toekomst vlug kan veranderen. Er mag worden geconcludeerd dat het uitleveringsrecht bezig is met een opmars in de rechtspraak van het Hof van Justitie. De tijd zal leren of het Pisciotti in de Nederlandse rechtspraak net zo vergaat. bij vervolgingsuitlevering. Om die reden is er wel een belemmering van vrij verkeer.

44. Klip stelt in zijn noot bij het arrest Aleksei Petruhhin dat rechtshulpverzoeken onbeperkt kunnen worden gedaan. Het is goed mogelijk dat een derde staat een nieuw verzoek doet aan de Nederlandse autoriteiten, nadat een $E A B$ is uitgevaardigd en de opgeëiste persoon naar Nederland is overgebracht.

45. H.D. Sanders en J.M. Sjöcrona, 'Overdracht en overname van de tenuitvoerlegging van buitenlandse strafrechtelijke beslissingen', in: E. van Sliedriegt, J.M. Sjöcrona en F. Orie, Handboek Internationaal Strafrecht. Schets van het Europese en Internationale Strafrecht, Deventer: Kluwer 2008, 329. Conversie van de buitenlandse straf op grond van de art. 28, 30 en 31a WOTS zorgt ervoor dat een buitenlands vonnis in Nederland tenuitvoergelegd kan worden conform art. 553 e.v. Sv.

46. Overdracht van de tenuitvoerlegging kan onder andere geschieden op basis van het Verdrag inzake de overbrenging van gevonniste personen, Trb. 1983, 74. Ook landen buiten Europa zijn partij bij het verdrag, zoals de VS. 